Poulter, Benjamin, Rebecca L. Feldman, Mark M. Brinson, Benjamin P. Horton, Michael K. Orbach, Samuel H. Pearsall, Enrique Reyes, Stanley R. Riggs, and John C. Whitehead (2009) Sea-Level Rise Research and Dialogue in North Carolina: Creating Windows for Policy Change, Ocean and Coastal Management 52(3-4):147-153 (Mar - Apr 2009). Published by Elsevier (ISSN: 0964-5691). doi:10.1016/j.ocecoaman.2008.09.010

\title{
Sea-Level Rise Research and Dialogue in North Carolina: Creating Windows for Policy Change
}

\author{
Benjamin Poultera, Rebecca L. Feldman, Mark M. Brinsond, Benjamin P. Hortonf, \\ Michael K. Orbach, Samuel H. Pearsallg, Enrique Reyesd, Stanley R. Riggsd, John C. \\ Whitehead
}

\begin{abstract}
Coastal areas are among the world's most vulnerable landscapes to impacts related to climate change, including inundation from sea-level rise (SLR), increased exposure to shoreline erosion, and greater frequency and intensity of storms. The status of research on the physical, ecological, and socio-economic effects of vulnerability to SLR and progress toward planning for its consequences varies from region to region worldwide. Here, we synthesize the results of three decades of SLR research and the development of coastal management policies in North Carolina, USA. We identify the major factors responsible for opening new policy 'windows' that address SLR, including how stakeholders have developed an increased understanding of the risks, the extent of public dialogue about potential response strategies, and advances in political receptivity to policy change. Research and policy progress in North Carolina continue to provide a model for other regions to help guide and evaluate the development of coastal policies.
\end{abstract}




\section{INTRODUCTION}

Coastal areas are among the world's most vulnerable landscapes to climate change and its effects on sea level [21]. Global sea level is rising at a rate of 1-2 mm yr-1, largely due to expansion of the oceans as they warm and from additional melt-water from glaciers and ice sheets [22]. Direct impacts associated with rising sea level include inundation and increased susceptibility to changes in hurricane frequency and intensity [34]. Globally, at least 2 million $\mathrm{km} 2$ of coastal areas are vulnerable to climate change effects, with over $60 \%$ of world population at risk [48]. Over long time scales, human and ecological systems have adapted to sea-level rise (SLR), as evidenced by patterns of human settlement [10] and the evolution of coastal wetlands [30]; however, the size and permanence of today's coastal societies and infrastructure have lowered their resilience to external change, including the capacity for adaptation [33].

Recent results from global climate models suggest that rates of SLR will continue to increase over the next century [22]. Governments, researchers, and management institutions are investigating potential climate impacts across multiple sectors in coastal environments (Table 1). In this paper, we review issues related to SLR being studied in North Carolina (USA) and discuss recent factors advancing policy changes related to SLR.

\begin{tabular}{ll}
$\begin{array}{l}\text { Table } 1 \\
\text { Examples of some of the issues associated }\end{array}$ & with SLR. \\
\hline Research/Policy Sector & Issues being addressed (examples) \\
\hline Physical & Inundation modeling \\
& Erosion and setbadss \\
& Shoreline hardening implications \\
& Groundwater hydrology modeling \\
Ecological & Forest retreat \\
& Marsh loss and migration \\
& Habitat loss or creation \\
Socio-Economic & Land-use planning and zoning \\
& Insurance coverage \\
& Effects on tourism and property values \\
& Implications of policy options \\
& Adaptation and mitigation \\
\hline
\end{tabular}

\section{NORTH CAROLINA LANDSCAPE AND SLR HISTORY}

Coastal North Carolina has over $5900 \mathrm{~km}^{2}$ of land below 1-m elevation (Fig. 1), making it the third largest low-lying region in the United States, following Louisiana and Florida [52]. Recent coastal research indicates modern rates of relative SLR (over the last 100 years) may be more rapid than the long-term rate of rise over the last 800-1000 years [11], [15] and [19]. In North Carolina, based on coupled instrumental and salt marsh proxy data (including sedimentation and foraminifera records), Kemp et al. [24] suggested that SLR accelerated from a Late 
Holocene average of $1.1 \mathrm{~mm} \mathrm{yr}^{-1}$ to over $4 \mathrm{~mm} \mathrm{yr}^{-1}$ between 1800 and 2006. Based on tide gauge measurements analyzed by the National Oceanic and Atmospheric Administration [35], the measured rate of relative SLR in North Carolina ranges from 1.79 to $4.27 \mathrm{~mm} \mathrm{yr}^{-1}$, with rates increasing from south to north, reflecting isostatic variability and geologic subsidence. Global climate model projections from the Intergovernmental Panel on Climate Change Third [28] and Fourth Assessment Reports [22] project increasing temperature (Fig. 2a), but no consistent trend in changes in precipitation in coastal North Carolina (Fig. 2b). Most significantly, sea level is projected to rise an additional $50-100 \mathrm{~cm}$ or more by 2100 , with much of the uncertainty related to assumptions regarding the rates of Greenland and Antarctic icecap melt (Fig. 2c, see Rahmstorf [42]).

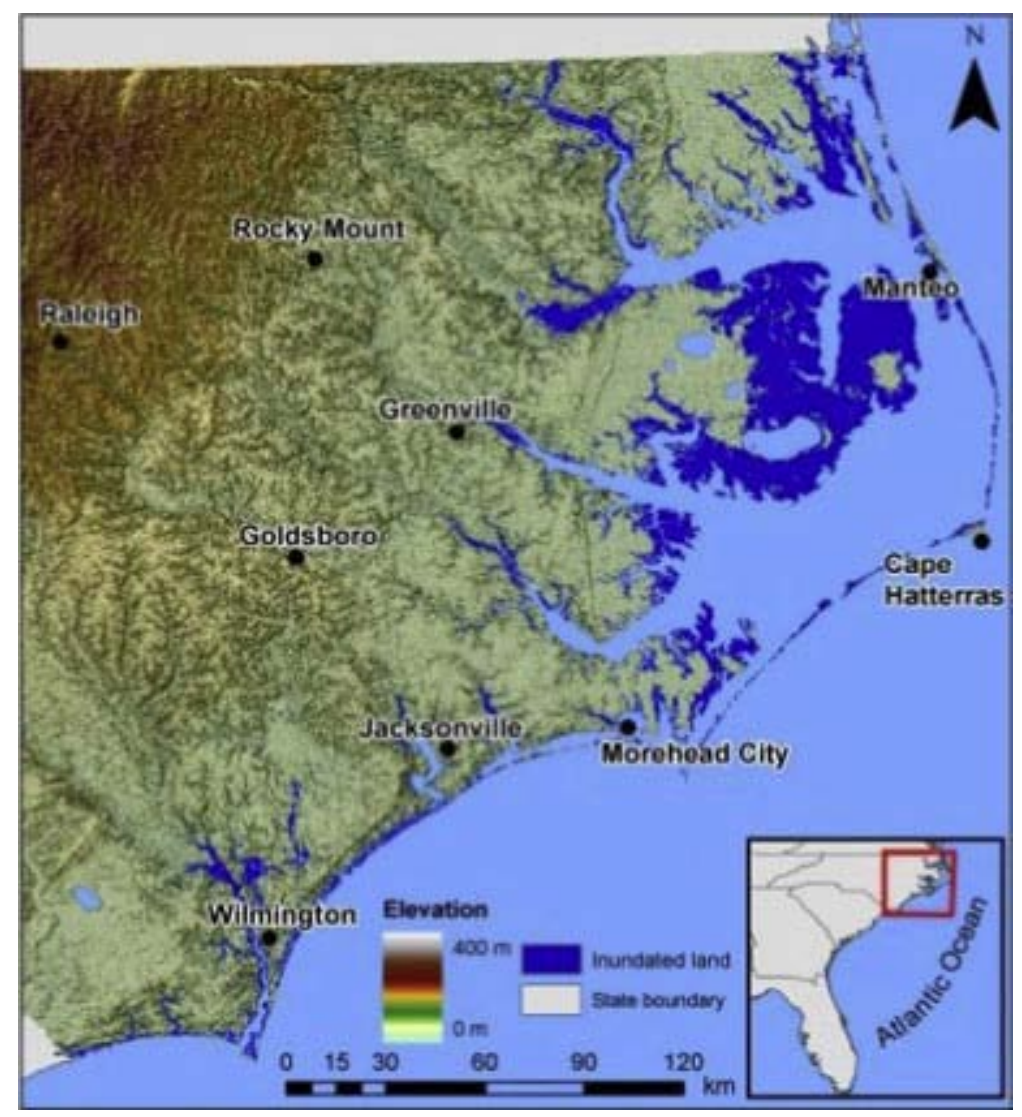

Fig. 1. Approximately $5900 \mathrm{~km}^{2}$ of coastal land is vulnerable to a 1.1-m rise in sea level projected for the year 2100 for the State of North Carolina. This estimate is based on the upper estimate from the IPCC Third Assessment Report (TAR) and includes the additional effect of SLR from isostatic subsidence ( $0.2 \mathrm{~m}$ per century). The methods for inundation following the approach described by Poulter and Halpin [41] using topographic LIDAR. 

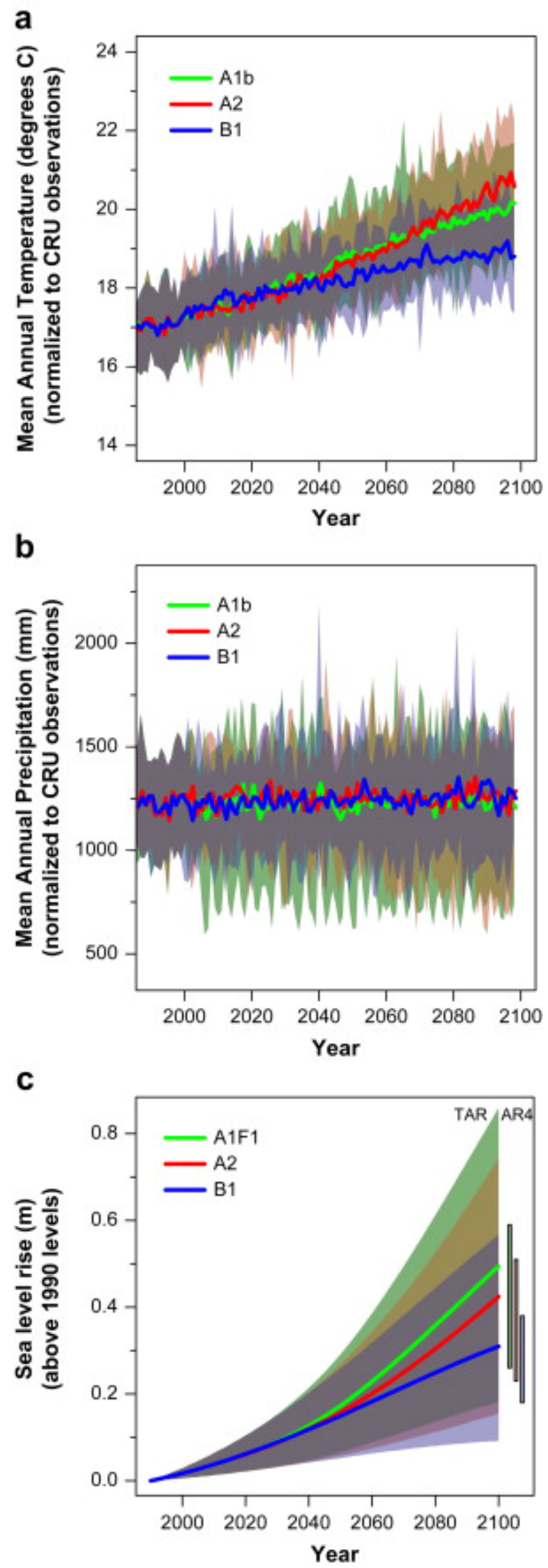
Fig. 2. a-c: Projected range of temperature (a) and precipitation (b) for coastal North Carolina from climate modeled in the latest IPCC Fourth Assessment Report [22]. The general circulation model (GCM) data are standardized to 20th Century climate data available from the Climatic Research Unit [32] climatology to account for consistent bias that may exist between models (or deviations from the mean). (c) Projected SLR from the IPCC Third and Fourth Assessment Reports (does not include regional isostatic subsidence $+0.2 \mathrm{~m}_{\text {century }}{ }^{-1}$ ). The confidence limits are based on the upper and lower global climate model estimates using scenarios based on the Special Report on Emission Scenarios (SRES).

\subsection{Sea-level rise warning signs}

North Carolina's vulnerability to SLR was recognized 20 years ago at a workshop at East Carolina University, where participants recommended two categories for future research: (1) models of and data on physical and biological responses to SLR and (2) developing management policies that mitigate potential negative impacts on wetlands and other coastal resources as sea-level rises [5]. Workshop participants promoted reducing uncertainties associated with the relationships between ecological processes, human influences, and SLR. Since then, a variety of field studies around the State have provided data on the effects of SLR on forest retreat [3], [17] and [40], shoreline erosion [44] and [45], salt-intrusion [54], and wetland accretion [55]. Other (less understood) warning signs of SLR impacts include agricultural abandonment (personal observation), loss of waterfront property [44], increasing numbers of marsh ponds [40], and tree-ring evidence suggesting increased plant stress over the past two decades [39].

Progress within each research sector (physical, ecological, and socio-economic) and associated dialogue among stakeholders affect the readiness of policy-makers to consider changes to adapt to and mitigate SLR. Here, we outline the development of this research by sector and illustrate how policy responses are evolving.

\section{REVIEW OF SECTORS}

\subsection{Physical effects}

The northeastern part of the North Carolina coast, from Cape Lookout north to the Virginia line, is characterized by $275 \mathrm{~km}$ of barrier islands and is broken by 4 inlets, compared to 18 inlets along the $225 \mathrm{~km}$ of coast from Cape Lookout to the South Carolina line [45]. The northeastern barrier islands separate the Atlantic Ocean from the large Albemarle-Pamlico estuarine system that includes over $6000 \mathrm{~km}^{2}$ of estuarine waters characterized by micro-tidal, low-salinity conditions due to limited exchange with the ocean [6]. Major features of the Coastal Plain were shaped by sea-level fluctuations during multiple Pleistocene glacial and interglacial episodes [37] and [46], creating ancient terraces and associated beaches across the Coastal Plain, the most prominent of which is the Suffolk Shoreline. These fluctuations in sea level are strongly related to depositional and erosive processes that shaped the complex antecedent topography 
upon which the current land surface is built [37]. During the mid-Holocene, extensive freshwater peat formation was initiated in the lower, poorly drained areas of the Pamlico Terrace east of the Suffolk Shoreline, and this peat currently stores more than $200 \mathrm{Tg}$ of carbon [20]. Many of these peatlands have been ditched and drained, creating conditions favorable for soil carbon loss via oxidation, inundation, erosion, and salt-intrusion [18].

The first landscape-scale assessment of North Carolina's vulnerability to SLR, by Moorhead and Brinson [29], estimated that there were $2800 \mathrm{~km}^{2}$ of land below $1.5 \mathrm{~m}$ elevation in northeastern North Carolina alone. This was followed by a U.S. Environmental Protection Agency (EPA) national assessment that projected a total of approximately $5800 \mathrm{~km}^{2}$ of land below $1.5 \mathrm{~m}$ for the entire state, using coarse resolution data with a $1.5 \mathrm{~m}$ contour interval [52]. Recently, as higher resolution topographic data have become available, Poulter and Halpin [41] mapped $5300 \mathrm{~km}^{2}$ of land at or below $1.1 \mathrm{~m}$ using LIDAR elevation data with a vertical resolution of $\pm 25 \mathrm{~cm}$ (Fig. 1). These inundation scenarios used simplified assumptions about ecological processes and the timing of physical impacts that may either mitigate or exacerbate the effects of SLR (e.g., the scenarios do not model wetland feedbacks responding to SLR). They also did not take into account potential feedbacks that may generate non-linear rates of change [40] and [55].

Non-linear responses to climate change are anticipated for the entire Outer Banks Barrier Island system [45]. During episodes of SLR, barrier islands naturally migrate landward in response to two processes. First, storms open inlets in weak barrier segments, and island width expands through the deposition of vast flood-tide deltas. Second, overwash buries the flood-tide deltas and builds barrier island elevations. Currently, these two processes are prevented or inhibited by the construction of dune ridges and roads. Consequently, erosion along both ocean and estuarine shorelines causes islands to narrow, thus increasing their vulnerability to storms and new inlet creation. Over the long term, one or more major storms could initiate a general collapse of sediment-poor barrier segments, causing major changes to the estuarine system [44].

The next generation of inundation mapping will consider these various feedbacks and non-linear responses by focusing on integrated hydrodynamic simulation modeling. These models will include the effects of SLR and tidal processes on shoreline shape and position, as well as ecological responses, i.e., vertical accretion [43]. On the ocean side, advances in modeling interactions between SLR and storm frequency show that the dynamics of shorelines are driven by variable erosion rates, significantly affected by sediment supply, and by subsequent patterns of alongshore sand transport [49]. While previous inundation models provide a valuable look at landscape vulnerability, key physical and ecological feedbacks such as these and spatial variation must be considered.

\subsection{Ecological effects}

North Carolina's terrestrial and aquatic ecosystems encompass tremendous biological diversity at both the species and plant-community scale [7]. Aquatic systems include extensive seagrass 
habitat and oyster reefs. Terrestrial habitats include extensive smooth cordgrass (Spartina alterniflora) and black-needlerush (Juncus roemerianus) wetlands, sawgrass (Cladium jamaicense) marshes, regional pocosin pine forests ('swamp on a hill' wetland forests), and pine or hardwood flatwoods (Fig. 3a). Various federal and state-level endangered, threatened or rare wildlife species [36], including the American alligator (Alligator mississippiensis), sea turtles (e.g. Chelonia mydas, the green turtle), and red-cockaded woodpecker (Picoides borealis), live in the region, and habitat loss from land-use change is affecting populations of diamond-backed terrapins (Malaclemys terrapin) and river herring (Alosa spp.).
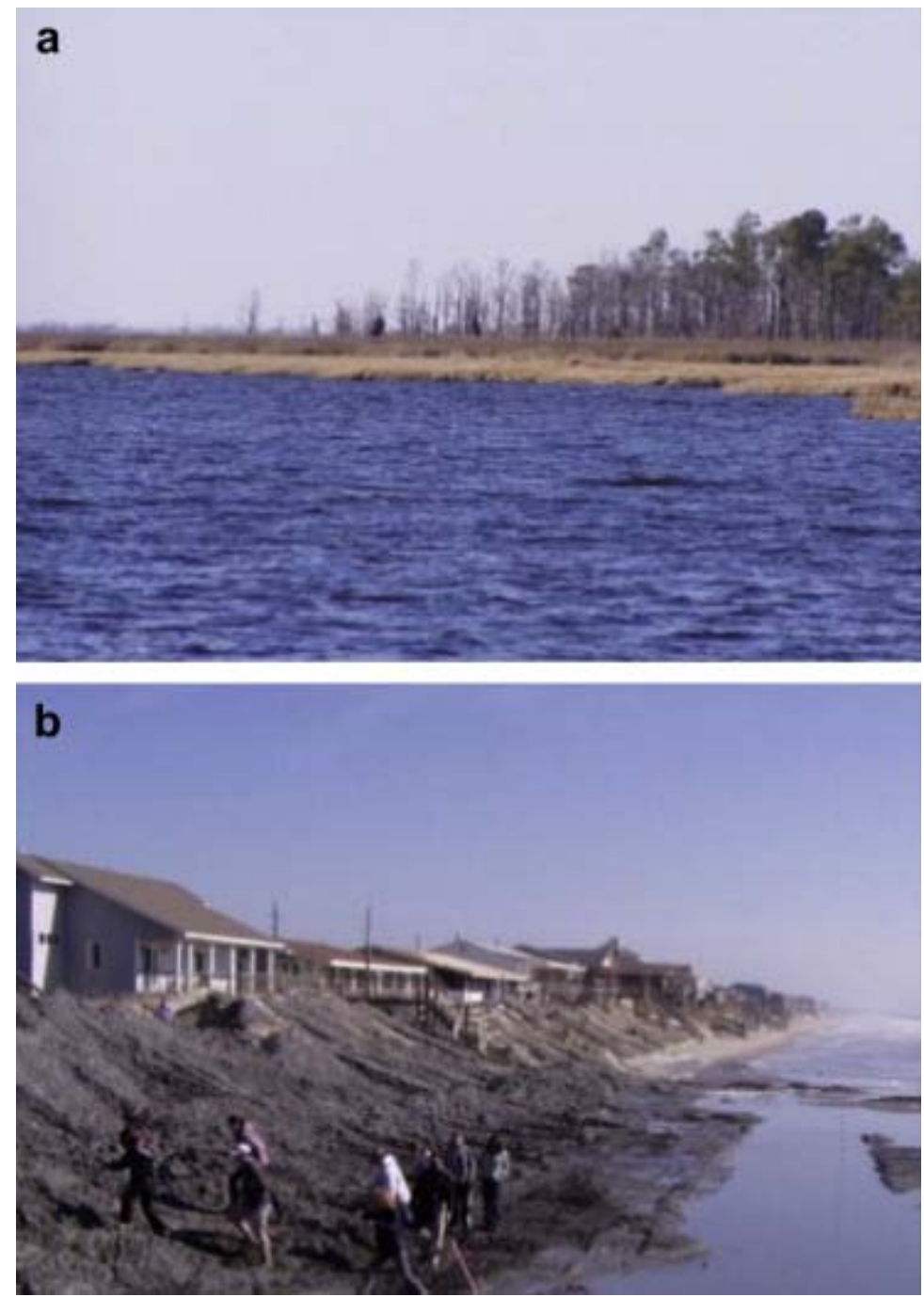

Fig. 3. a-b: (a) Typical estuarine vegetation gradient on Pamlico Sound, NC, illustrating black needlerush to loblolly pine forest in various stages of health. (b) Example of barrier island development, shoreline erosion, and beach nourishment (darker colored sand is in the process on being 'pumped' onto land). (Photographs by Ben Poulter). 
While dead and dying coastal forests have been observed for some time [3] and [4], only recently did aerial photograph analysis quantify the rate of overland migration of wetland habitat [40]. Inland coastal tree-line migration rates were 1-12 $\mathrm{m} \mathrm{yr}^{-1}$, depending on the rate of adjacent shoreline erosion and disturbance history [40]. Marsh habitat loss from erosion was generally mitigated by newly formed marsh further inland (replacing forest habitat), but forest formation was limited due to more intensive land-use activities in uplands [40].

Modeling future wetland loss due to SLR is sensitive to estimates of vertical accretion rates and sediment accumulation (raising surface elevation and partially mitigating inundation [30]). Recent rates of accretion in North Carolina's wetland forests are $0.26-1.0 \mathrm{~mm} \mathrm{yr}^{-1}$ [8], while in some marshes the rates have been up to 2.0-3.0 $\mathrm{mm} \mathrm{yr}^{-1}$ [9]. Vertical accretion is primarily limited by sediment transport to wetland surfaces in the Albemarle-Pamlico Sound [53]. Recent observations of interior pond development also suggest accretion may be limited by sediment supply [40]. However, management practices, especially the reintroduction of fire, can strongly influence above ground organic matter accumulation and possible sediment retention [16]. Whether wetlands can maintain higher rates of vertical accretion with faster rates of SLR remains uncertain [30]. The amount of suspended sediment available and the rate of sea-level rise affect how vegetated areas respond to SLR, a higher sediment supply is correlated with greater rates of sediment deposition, while higher rates of SLR causes channels to deepen [14] and [26].

Changes in the estuarine system driven by SLR and associated direct effects on species populations are equally uncertain and will be determined by large-scale processes, such as the fate of large stores of disintegrating terrestrial peats that could strongly influence estuarine biogeochemistry [18] or a collapse of a portion of the barrier islands and the conversion of estuarine to pelagic conditions [45]. These and other processes associated with climate change and local human activities (discussed next) may result in non-linear responses and novel conditions that are associated with high levels of uncertainty.

\subsection{Socio-economic effects}

North Carolina's coast has relatively low population density compared to the rest of the United States Atlantic seaboard. The U.S. Census Bureau estimates that, in 2005, approximately 900,000 people lived in the 20 coastal counties, and, between 1990 and 2000, population increased by $16 \%$. Population growth and second home development have accelerated demand for coastal housing. The Census Bureau also indicates that, in the three most populated coastal counties, Carteret, Dare and New Hanover, the number of housing units increased by 18-39\% from 1990 to 2000. Property values increased rapidly, with $\$ 43$ billion dollars of property in these three coastal counties [2]. Similar economic trends can be seen in many coastal areas, creating additional pressure for coastal managers.

Coastal North Carolina is characterized by complex ownership patterns; in addition to residential property, family farms, and businesses, large parcels are held by the U.S. Department of Defense, U.S. Fish and Wildlife Service, State of North Carolina, timber and agriculture 
corporations, non-governmental organizations, and real estate developers. The counties most vulnerable to SLR in the northeast portion of the State (excluding the barrier island portion of Dare Country) are the State's poorest counties and among the poorest in the USA, according to the U.S. Census Bureau and the North Carolina Department of Commerce economic well-being index. The coastal economy is changing, and the fishing industry, which once sustained local economies, has been overshadowed by development and tourism. Currently, coastal tourism accounts for approximately $\$ 2.6$ billion $\mathrm{yr}^{-1}$ (North Carolina Department of Environment and Natural Resources 2005).

Estimates of the impact of SLR on coastal economies must consider a suite of potential impacts, including increased exposure to coastal erosion (Fig. 3b) and direct inundation on various sectors, such as recreation, business, and private property [2]. For just four coastal North Carolina counties, the negative impact of SLR on property values has been estimated at up to $\$ 6.9$ billion by 2080 , along with statewide recreation losses (beach visits) valued at $\$ 3.5$ billion between 2005 and 2080, due to increased erosion (largely due to storms) and narrowed and steepened beaches [2]. Negative recreational fishing impacts were valued at $\$ 430$ million between 2005 and 2080, due to loss of present fishing locations [2]. These estimates did not consider the additional economic cost of maintaining beach widths by adding sand and filling new inlets, up to millions of dollars per year per beach segment.

The configuration of private property holdings makes adaptation to SLR challenging because many vulnerable lowland habitats cannot naturally migrate inland due to ownership patterns (Fig. 4). Property rights issues will emerge after private property is submerged and, as a result, become the property of the State (see Ref. [56]). Potential mechanisms to address these challenges include stakeholder dialogue, collaborative management, and various land protection strategies, such as easements and life estates. Easements could include 'rolling easements,' which prohibit only shoreline stabilization structures and allow other property uses and the occupation of buildings until sea level reaches them, at which time they must be abandoned or removed [50]. 


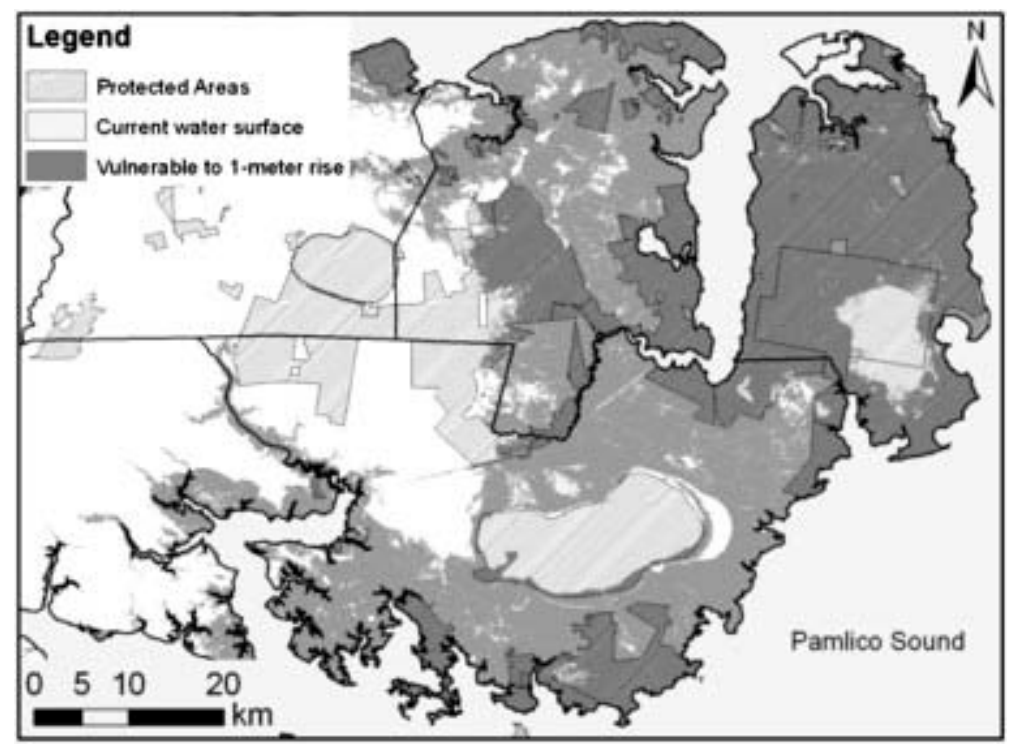

Fig. 4. The configuration of property ownership in coastal North Carolina, as shown in this map of the Albemarle-Pamlico peninsula, will make it difficult for wetland habitats to migrate into upland areas (as they become wetter with SLR) because of upland private property ownership (in white) and land-use patterns.

\section{ADAPTATION AND MITIGATION}

One of the common themes emerging from research in coastal North Carolina is that land management interacts strongly with SLR, increasing the rate of physical and ecological change. Certain management strategies might mitigate the patterns and rates of ecosystem change. Land management activities that interact with SLR include forest clearing and planting, management of drainage canals (which can transport saltwater into freshwater areas), dredging, shoreline hardening (installing groins, seawalls, bulkheads, etc.), and shoreline development. For example, the reintroduction of fire following suppression increased rates of marsh invasion following forest mortality [40], and dredging of shipping channels increased tidal amplitude of the Cape Fear River, causing widespread forest inundation and die-off [17]. Similarly, locating houses close to dynamic shorelines has resulted in increased property losses as beaches and dunes are naturally reconfigured or reclaimed by the ocean [44].

Possible adaptation and mitigation responses to SLR are wide-ranging and include aquatic and terrestrial restoration (e.g., assisted species dispersal [27]), changes in the land management practices described above, and inclusion of SLR considerations in long-term county planning and development [38]. Reducing losses of ecosystem services could also prevent significant terrestrial carbon release, and carbon offset projects present possible financing mechanisms [18]. Aquatic restoration, such as of oyster reefs, could also have significant co-benefits by reducing rates of shoreline erosion through dissipating wave energy [38]. 
Strategies for preventing property loss are complex and constrained by regional policy and politics, as well as environmental concerns. In 1985, North Carolina banned hardened structures on the oceanfront because they negatively affect sediment transport and coastal erosion on adjacent beach segments. Instead, the State allows beach nourishment and temporary sandbag installations in front of oceanfront properties. Hardened structures are allowed along the estuary, which could result in SLR squeezing out wetlands. To protect property from SLR, other management options include more frequent nourishment (which has ecological and economic impacts), reclassifying hazard zones and strengthening land-use regulations within them, changing setback regulations, elevating or moving structures, and total abandonment.

\section{FRAMEWORK FOR EVALUATING READINESS FOR POLICY CHANGE}

While researchers and coastal managers have been promoting awareness of the potential effects of SLR on North Carolina since the mid-1970s, few policies have been implemented to reduce SLR-related impacts. More immediate socio-economic issues, a general political climate opposed to regulation, and the fact that, until recently, most state policy-makers lacked sufficient information about risks associated with SLR have impeded policy change and diverted people's attention from the problem in North Carolina [31].

Moser [31] suggests that actions to address problems such as SLR will be taken when the understanding of potential impacts, dialogue about response strategies, and politics converge (Fig. 5). When these three processes, what has been referred to as the 'problem stream,' the 'policies stream,' and 'political stream,' come together, a 'policy window' opens, creating opportunities for policy change [25] and [31]. While these opportunities are sometimes created by the appearance of compelling problems or events in the political stream, policy windows are often scarce. For policy change to occur during open windows, viable policy alternatives that have been discussed publicly need to be available to policy-makers. In considering strategies, decision-makers focus on policy alternatives that are feasible, affordable, and publicly acceptable [25]. 


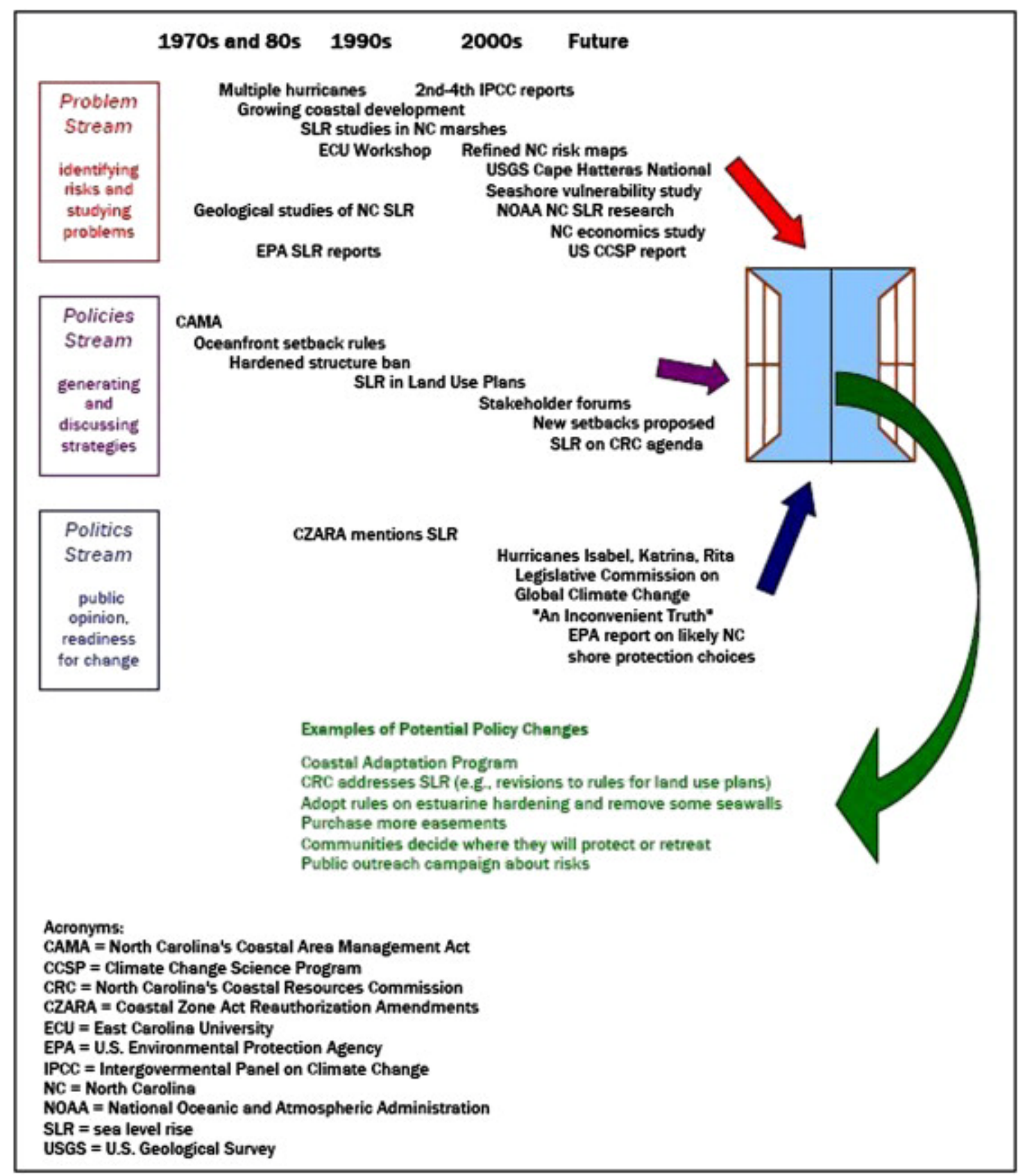

Fig. 5. This timeline shows events related to North Carolina SLR research and policy in the problem, policies, and politics streams from the 1970s to the present and how their confluence has opened a policy window, consistent with Kingdon's [25] model. Also shown are examples of potential policy changes related to preparing for and mitigating SLR impacts that might be made during the open policy window. For policy change to occur, the risks related to SLR need to be appreciated and on the agenda of policy-makers, responses must have been proposed, and key stakeholders must be amenable to change. 
Important elements of the problem, policies, and political streams related to SLR in North Carolina are shown in Fig. 5. Beginning in the 1970s, North Carolina was interested in managing coastal development. The State mandated new oceanfront development be set back a distance of 30 or 60 times the long-term erosion rate at a particular location. In 2000, a 10meter setback was added for development along the estuarine shoreline. These setbacks may indirectly encourage retreat from the coastline, but they do not take into account changes in long-term erosion rates, buildings that last more than 30-60 years, existing development, or major shoreline changes in response to one or a series of major storm events. Any existing structure imminently threatened by the ocean is supposed to be removed within two years, but this is not consistently enforced [13].

By 1990, attention was being paid to SLR at the federal and state levels. For example, the federal Coastal Zone Act Reauthorization Amendments of 1990 identified a need for planning efforts to consider SLR. This may have sparked a provision in North Carolina's subsequent regulations requiring land-use plans in coastal counties to consider minimizing threats from development in areas susceptible to SLR. However, most counties have deferred making decisions about these areas until the future, when more information becomes available [13]. SLR did not otherwise make it onto the policy agenda in North Carolina in the 1990s because there was so little activity related to associated risks in the political stream.

In the last several years, activities related to SLR risk in North Carolina have occurred in all three streams. First, the research described above has allowed stakeholders to better understand the problems. Second, dialogue about potential solutions has also increased. To promote direct consideration of policy responses to SLR, EPA funded research to evaluate potential local responses to SLR in coastal states, including North Carolina [51]. County planners were asked to identify locations they expected would be protected, might be protected, or were unlikely to be protected from SLR, for the first time mapping areas where action to mitigate SLR impacts might occur. Communication among stakeholders is also increasing: EPA, NOAA, USGS, and The Nature Conservancy have held various meetings with participants from local, state, and federal agencies and nonprofit organizations to discuss SLR management and scientific needs [1]. When stakeholders are educated about risks and public dialogue has occurred, policy change is more likely to result. Recent research has also outlined policy recommendations for North Carolina to consider to begin to address SLR vulnerabilities [12] and recommendations about how to present information about SLR to encourage people in North Carolina to become educated about SLR risks and support associated planning efforts [13]. While expert testimony and outreach can impact policy formation and implementation [31], the influence of skeptics and conservative think-tanks may interfere with this progress [23].

The political climate in North Carolina seems to have begun to favor action on SLR. In 2005, North Carolina established a Legislative Commission on Global Climate Change to assess potential impacts of global climate change and the costs and benefits of mitigation strategies. One outcome has been a discussion of a potential Coastal Adaptation Program that could purchase land or conservation easements in high risk areas, require hazards associated with coastal properties be disclosed to prospective buyers, and conduct public education and outreach about climate change [47]. 
It appears a policy window is open in North Carolina. The Legislative Commission on Global Climate Change will soon release recommendations, and North Carolina's Coastal Resources Commission has actively begun discussions of SLR beginning in 2007. Research continues on the effects of SLR on the State and ways to address them. Scientists are focusing on making their research most useful to policy-makers. Finally, numerous parties have committed to encouraging action on adapting to SLR impacts. These include nonprofit and research institutions. For example, over the past 5-10 years, several policy institutes have been established at North Carolina universities with coastal issues at the forefront of their agenda.

\section{CONCLUSION}

The recent history of SLR research, dialogue, and coastal planning in North Carolina provides a valuable example for other coastal regions (Fig. 5). Globally, the risks associated with SLR will disproportionately affect low-lying areas, including in many developing countries, as well as highly-populated areas. While some coastal areas have been developed with vulnerability to flooding in mind (e.g., London's Thames River flood barrier and Holland's extensive dike and pump networks), others have not yet explored mitigation strategies. In many regions, vulnerabilities to inundation are highly uncertain and physical processes related to shoreline change and hydrologic responses are poorly understood, impeding readiness to make policy decisions. For widespread progress to occur toward thoughtful new policies responding to SLR, some of the drivers (research progress and understandings of the problems, availability of and dialogue about potential responses, and political climates) must change, opening policy windows for stakeholders.

\section{ACKNOWLEDGEMENTS}

We would like to acknowledge financial support from the North Carolina Sea Grant Program, the National Aeronautics and Space Administration (NGT5-30472), the Environmental Protection Agency, the National Oceanic and Atmospheric Administration, and the United States Geological Survey. 


\section{REFERENCES}

[1] Auer C. Ecological effects of sea level rise: a new research program sponsored by the NOAA's Center for Sponsored Coastal Ocean Research. National Oceanic and Atmospheric Administration; 2004. Workshop Report.

[2] Bin P, Dumas C, Poulter B, Whitehead J. Measuring the impacts of climate change on North Carolina coastal resources. Boone, NC: Department of Economics, Appalachian State University; 2007. p. 101.

[3] Brinson MM, Bradshaw HD, Jones MN. Transitions in forested wetlands along gradients of salinity and hydroperiod. Journal of the Elisha Mitchell Scientific Society 1985;101:76-94.

[4] Brinson MM, Christian RR, Blum LK. Multiple states in the sea-level induced transition from terrestrial forest to estuary. Estuaries 1995;18:648-59.

[5] Brinson MM, Moorhead KK. Sea level rise and fringe wetlands in North Carolina: recommendations from a workshop on management and research.

Journal of the Elisha Mitchell Scientific Society 1989;105:149-57.

[6] Buzzelli CP, Ramus JR, Paerl HW. Ferry-based monitoring of surface water quality in North Carolina estuaries. Estuaries 2003;26:975-84.

[7] Christensen NL. Vegetation of the coastal plain of the southeastern United States. In: Barbour M, Billings WD, editors. Vegetation of North America. 2nd ed. Cambridge, UK: Cambridge University Press; 2000.

[8] Craft CB, Richardson CJ. Recent and long-term organic soil accretion and nutrient accumulation in the Everglades. Soil Science Society of America Journal 1998;62:834-43.

[9] Craft CB, Seneca ED, Broome SW. Vertical accretion in microtidal regularly and irregularly flooded estuarine marshes. Estuarine Coastal and Shelf Science 1993;37:371-86.

[10] Day JW, Gunn JD, Folan WJ, Yanez-Aranciba A, Horton BP. Emergence of complex societies after sea level stabilized. Earth and Ocean Systems Transactions of the American Geophysical Union 2007;88:169-70.

[11] Donnelly JP, Cleary P, Newby P, Ettinger R. Coupling instrumental and geological records of sea-level change: evidence from southern New England of an increase in the rate of sea-level rise in the late 19th century. Geophysical Research Letters 2004;31:L05203.

[12] Feldman RI, Oahu HI, Reston VA. In: A.S. o. C. Engineers, editor. Recommendations for responding to sea level rise: lessons from North Carolina. Oahu, HI:

Solutions to Coastal Disasters; 2008.

[13] Feldman RL. Planning for sea level rise vulnerability in North Carolina. Masters thesis. Durham, NC: Duke University; 2007. 
[14] FitzGerald DM, Fenster MS, Argow BA, Buynevich IV. Coastal impacts due to sea-level rise. Annual Review of Earth and Planetary Sciences 2008;36:601-47. doi:/610.1146/annurev.earthy.1135.031306.140139.

[15] Gehrels WR, Kirby JR, Prokoph A, Newnham RM, Achterberg EP, Evans H, et al. Onset of recent rapid sea-level rise in the western Atlantic Ocean. Quaternary Science Reviews 2005;24:2083-100.

[16] Hackney CT, de la Cruz AA. Effects of fire on brackish marsh communities: management implications. Wetlands 1981;1:75-87.

[17] Hackney CT, Yelverton GF. Effects of human activities and sea level rise on wetland ecosystems in the Cape Fear River Estuary, North Carolina, USA. In: Whigham DF, Good RF, Kvet Y, editors.Wetland ecology and management: case studies. Amsterdam, The Netherlands: Kluwer Academic Publishers; 1990.

[18] Henman J, Poulter B. Inundation of freshwater peatlands by sea level rise: uncertainty and potential carbon cycle feedbacks. Journal of Geophysical Research 2008;113. doi:10.1029/2006JG000395.

[19] Horton BP, Corbett R, Culver SJ, Edwards RJ, Hiller C. Modern saltmarsh diatom distributions of the Outer Banks, North Carolina, and the development of a transfer function for high resolution reconstructions of sea level. Estuarine Coastal and Shelf Science 2006;69:381-94.

[20] Ingram RL. Peat deposits of North Carolina. Bulletin 88. Raleigh, NC: Department of Natural Resources and Community Development, Division of Land Resources, Geological Survey Section; 1987.

[21] IPCC. Climate change 2007: impacts, adaptation and vulnerability. Cambridge, United Kingdom and New York, NY, USA: Cambridge University

Press; 2007.

[22] IPCC. Climate change 2007: the physical basis. Contribution of Working Group I to the fourth assessment report of the intergovernmental panel on climate change. Cambridge, United Kingdom and New York, NY, USA: Cambridge University Press; 2007. p. 996.

[23] Jacques PJ, Dunlap RE, Freeman M. The organisation of denial: conservative think tanks and environmental scepticism. Environmental Politics 2008;17:349-85.

[24] Kemp A, Horton BP, Culver SJ, Corbett R, Thomson K, Van de Plassche O. In: Evidence for recent acceleration(s) in the rate of sea-level rise from the Albemarle-Pamlico estuarine system, North Carolina. Denver, CO: The Geological Society of America; 2007. p. 28-31, Oct 2007.

[25] Kingdon JW. Agendas, alternatives, and public policies. 2nd ed. New York, NY: Harper Collins College Publishers; 1995. 
[26] Kirwan ML, Murray AB. A coupled geomorphic and ecological model of tidal march evolution. Proceedings of the National Academy of Sciences 2007;

104:6118-22.

[27] McLachlan JS, Hellman JJ, Schwartz MW. A framework for debate of assisted migration in an era of climate change. Conservation Biology 2007;21:297-302.

[28] Mearns LO, Giorgi F, McDaniel L, Shields C. Climate scenarios for the southeastern U.S. based on GCM and regional model simulations. Climatic Change 2003;60:7-35.

[29] Moorhead KK, Brinson MM. Response of wetlands to rising sea level in the lower coastal plain of North Carolina. Ecological Applications 1995;5:261-71.

[30] Morris JT, Sundareshwar PV, Nietch CT, Kjervfe B, Cahoon DR. Responses of coastal wetlands to rising sea level. Ecology 2002;83:2869-77.

[31] Moser SC. Impact assessments and policy responses to sea-level rise in three US states: an exploration of human-dimension uncertainties. Global Environmental Change 2005;15:353-69.

[32] New M, Lister D, Hulme M, Makin I. A high-resolution data set of surface climate over global land areas. Climate Research 2002;21:1-25.

[33] Nicholls RJ. Coastal megacities and climate change. GeoJournal 1995;37: 369-79.

[34] Nicholls RJ. Coastal flooding and wetland loss in the 21st century: changes under the SRES climate and socio-economic scenarios. Global Environmental Change 2004;14:69-86.

[35] NOAA. North Carolina bathymetry/topography sea level rise project: determination of sea level trends. NOAA Technical Report NOS CO-OPS 041.

National Oceanic and Atmospheric Administration, Center for Operational Oceanographic Products and Services; 2004.

[36] North Carolina Natural Heritage Program. Guide to federally listed endangered and threatened species of North Carolina Division of Parks and Recreation; 2001.

[37] Parham PR, Riggs SR, Culver SJ, Mallinson DJ, Wehmiller JF. Quaternary depositional patterns and sea-level fluctuations, northeastern North Carolina. Quaternary Research 2007;67:83-99.

[38] Pearsall S, Poulter B. Adapting coastal lowlands to rising seas. In: Groom MJ, Meffe GK, Carrol CR, editors. Principles of conservation biology. 3rd ed. Sunderland, MA: Sinauer Press; 2005.

[39] Pederson N, Poulter B. Stand dynamics and climate sensitivity of an Atlantic white cedar (Chamaecyparis thyiodes) forest: implications for restoration and management. Richmond, KY: Eastern Kentucky University; 2006. p. 31. 
[40] Poulter B. Interactions between landscape disturbance and gradual environmental change: plant community migration in response to fire and sea level

rise. PhD dissertation. Durham, NC: Duke University; 2005.

[41] Poulter B, Halpin PN. Raster modeling of coastal flooding from sea level rise. International Journal of Geographical Information Sciences 2008;22:167-82.

[42] Rahmstorf S. A semi-empirical approach to projecting future sea-level rise. Science 2006. doi:10.1126/science.1135456.

[43] Reyes E, White ML, Martin JF, Kemp GP, Day JW, Aravamuthan V. Landscape modeling of coastal habitat change in the Mississippi Delta. Ecological

Applications 2000;81:2331-49.

[44] Riggs SR. Shoreline erosion in North Carolina's estuaries. Publication No: UNCSG01-11. Raleigh, NC, USA: North Carolina Sea Grant Program, North Carolina State University; 2001.

[45] Riggs SR, Ames DV. Drowning the North Carolina coast: sea-level rise and estuarine dynamics. Raleigh, NC, USA: North Carolina Department of Environment and Natural Resources, Division of Coastal Management, and North Carolina Sea Grant, North Carolina State University; 2003.

[46] Riggs SR, Cleary WJ, Snyder SW. Influence of inherited geologic framework upon barrier beach morphology and shoreface dynamics. Marine Geology 1995;126:213-34.

[47] Riggs SR, Stephenson JH, Clark W. Preliminary recommendations for mitigating the consequences of climate change within North Carolina. North Carolina Climate Change Commission; 2007. January 9th, 2007.

[48] Rowley R, Kostelnick JC, Braaten D, Li X, Meisel J. Risk of rising sea level to population and land area. Earth and Ocean Systems Transactions of the American Geophysical Union 2007;88:105-16.

[49] Slott JM, Murray AB, Ashton AD, Crowley TJ. Coastline responses to changing storm patterns. Geophysical Research Letters 2006;33:L18404,. doi:18410.11029/12006GL027445.

[50] Titus JG. Rising seas, coastal erosion, and the takings clause: how to save wetlands and beaches without hurting property owners. Maryland Law Review 1998;57:1279-399.

[51] Titus JG. Maps that depict the business-as-usual response to sea level rise in the decentralized United States of America. In: Global forum on sustainable development, development and climate change. Paris: OECD; 2004.

[52] Titus JG, Richman C. Maps of lands vulnerable to sea level rise: modeled elevations along the US Atlantic and Gulf coasts. Climate Research 2001; 18:205-28. 
[53] Wells J, Kim S. Sedimentation in the Albemarle-Pamlico lagoonal system: synthesis and hypotheses. Marine Geology 1989;88:263-84.

[54] Yanosky TM, Hupp CR, Hackney C. Chloride concentrations in growth rings of Taxodium distichum in a saltwater-intruded estuary. Ecological Applications 1995;5:785-92.

[55] Young DR. Coastal wetland dynamics in response to sea-level rise: transgression and erosion. PhD dissertation. Durham, NC: Duke University; 1995.

[56] N. C. Gen. Stat. x 146-64(6);2008. 